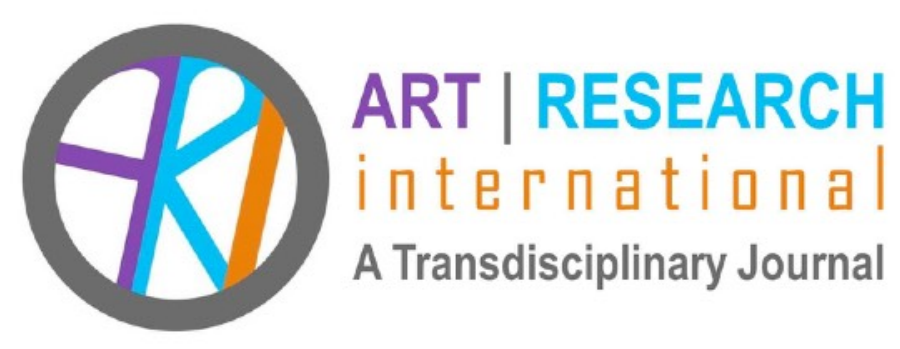

\title{
SAILING INTO AUSTRALIAN SETTLER FICTIONS: REFLECTION ON AN INQUIRY AND CONSTRUCTION WITH PERFORMANCE AND IMAGES
}

\section{Paul Reader Independent artist-performer preader@artlearn.net}

Paul Reader is an independent artist-performer, also a former Senior Research Fellow in Contextual Studies at the University of New England, Armidale, Australia. His career has spanned visual research, the community arts and community development with neighbourhood centres, environment groups and remote communities for over 30 years. Since 2014 he has worked closely with the Ardugula Aboriginal Corporation and Dunjiba Community Council at Oodnadatta, South Australia, resuming a connection to the community and country with which he first worked in the 1980s.

Abstract: This is reflection on artistic inquiry as an expedition, construction and modification of a watercraft, where image-making occurs en route. The journey is from the Queensland Gold Coast to the fringes of the Simpson Desert, undertaken in May-June 2018. The place of boats in Australian inland exploration is considered. The author-artist situates performance/art-making as a post-structural practice. Research or inquiry is seen partly as a self-realization occurring after the process has already begun. The origins of the craft and the expedition are also described. From the images the artist imagines the search for Burke and Wills, the lost explorers, as it might be conducted by boat. Encounters with 'Grey Nomads' are considered. An inland sea is discovered, and the existence of the Peoples Republic of Wangkangurra imaginatively arises in the vacated fringes of the Simpson Desert. Key images of the emergent inquiry are provided and discussed. Discoveries and 
disruptions of settler fictions are made, concluding on the value of the approach in challenging cultural authorities.

Keywords: expedition; boat; desert; walking-art; post-structuralism; grey-nomads; culturalauthority 


\section{The Formation of a Research Question through Performance and Image}

In art research or art as research, the idea of what makes inquiry is important; it influences how artists perform their work, construct or guide fluid media into form. In my case, as an artist unconstrained by an academic role, or any imperative to couch my work as research, it is quite normal for me to discover I am in the middle of a project before I have any intellectual understanding of where the project may be heading. I try to live mostly with my sensibilities and imaginings. This was true for the reflections and experiences in this project. Research often implies the framing or existence of a research question. Here the question was post-hoc. Not until I had completed a series of sailings, recorded several digital images - stills and very short videos, did I come to a realisation that I was creatively inquiring into something. "Something" was beginning to take shape. A novel thought caught my attention. I looked at a short video clip: a selfie of me sailing. Although I say "selfie," what is caught is the motion of the boat, a portrait of my actions rather than my body. I thought "I'm sailing in search of Burke and Wills," two immortalized Australian explorers who failed to return after crossing Australia (Moorehead, 1965). It was not their crossing, but their failure that assured them a place in settler history which is largely more myth than reality.

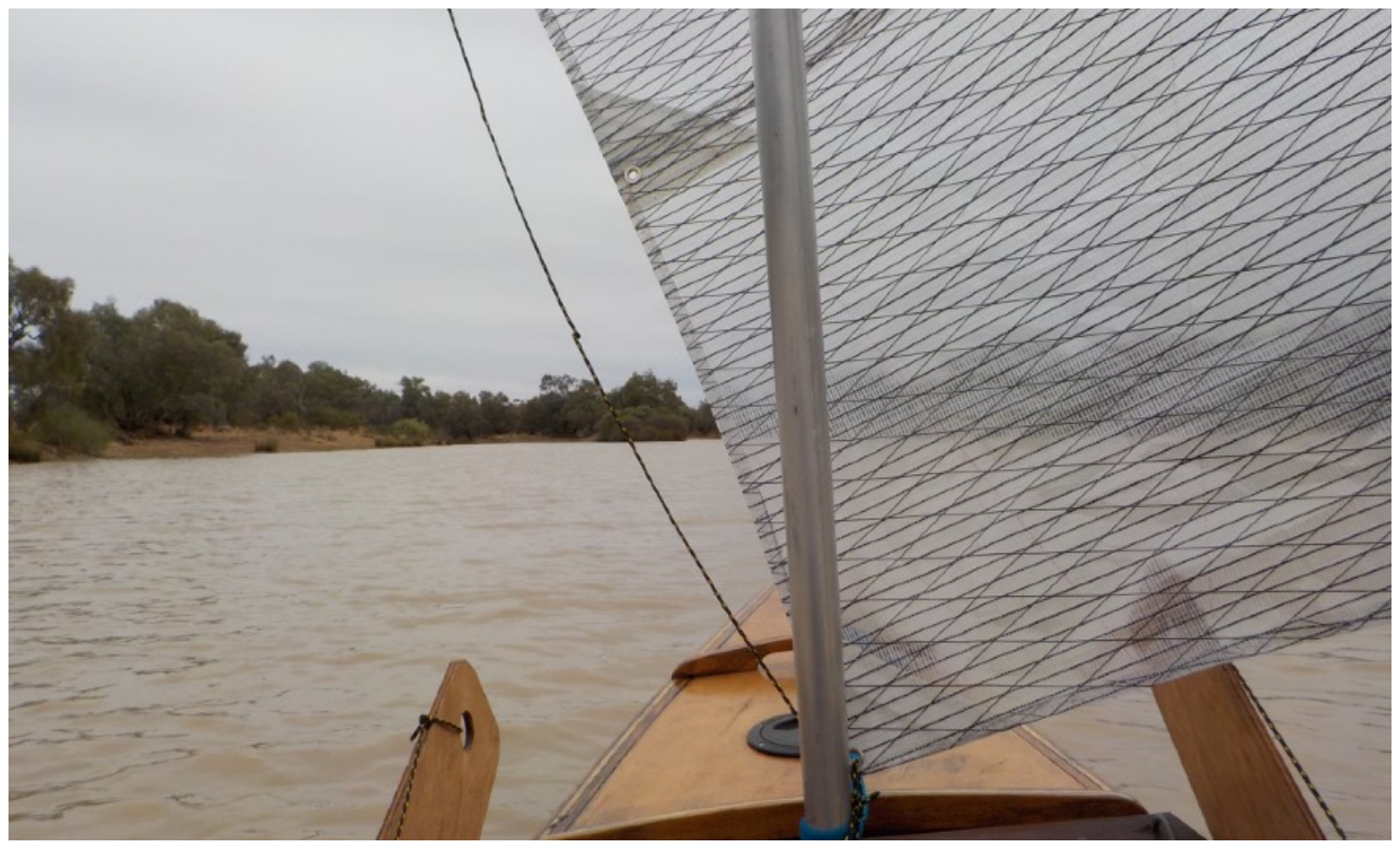

Figure 1. "I'm sailing in search of Burke \& Wills": Downwind at Noccundra

On framing this notion of sailing after lost expeditioners, I could then ask, "Well, is there a research question for this?" and, "Exactly what am I doing with a boat in this part of Australia and can something be made from these thoughts and images?" The research 
question became something like: "Is it possible to disrupt settler fictions and traditional narratives through nautical images and story-telling arising through changed conditions and the playful imagination of "the artist'?" This article reflects on the emergence of a project from these beginnings; its preconditions, various stages and events as an expedition, and ultimately the prospective products and outcomes arising from the inquiry about one month after my recognition of its existence.

\section{The Post-structuralist Performance, Construction, and Bricolage}

I see my own art-making as a form of post-structural performance, regardless of whether I am working with paint, constructing in some other medium, planting a tree or travelling. This "post-structuralism" emanates from the creative license of "fin de Sixties" British art-students' rejection of conventions such as tuition and craft approaches to media, exhibition, commercial art houses and gallery spaces (Charnley, 2015). Events, beliefs, rejections, grounded in the student revolutions of that period, led to a dismantling of conventions paralleled by the philosophical work of Derrida (1967/1980) which only later became conceptualised as "post-structuralism." Arguably, these rejections created challenges, but also aided "structures and conjunctures of cultural domination, as well as the cultural mechanisms" (Rubin, 2012, p. 8) at the time. Deep-state actors and agencies worked hard, during the Cold War period, to achieve North American supremacy in contemporary art, shifting focus from Paris to New York (Appy, 2000; Lofgren, 2016; Stonor Saunders, 1999). Ultimately this laid the ground for global neo-liberalism, the re-legitimation of art-houses and objects, exemplified by works like For the Love of God (Hirst, 2007). The art-politic of this more recent development has been well-explored by White (2009). I raise it here to situate my practice and inquiry as post-structuralist in a way that may have lost resonance in more recent times.

In my approach, sensibility, observations, images, the performance, actions and imaginings are used as whatever comes to hand. The emergence of inquiry or a work forms a bricolage of objects and life performance. Earlier works have included; walking from the Spencer Gulf, 800km inland, to the shores of Lake Eyre and beyond in 1984 (Reader, 2015); and also living on 3929 square metres of land in NSW which, coincidentally, would be the parcel size if the United Kingdom were equally divided among its inhabitants (Reader, 2013). This application of artistry to life and its performance creates both intention and falseconfidence in breaking with conventional cultural constraints. My artist-self is a performer who constructs, uses fluid media and images in life-making. In the course of life-work and life-learning, projects and objects may or may not get constructed, may get half-constructed and abandoned, or may be completed without any celebratory aspect or labelling as art. This is the context in which I reflect on the project and its becoming. 


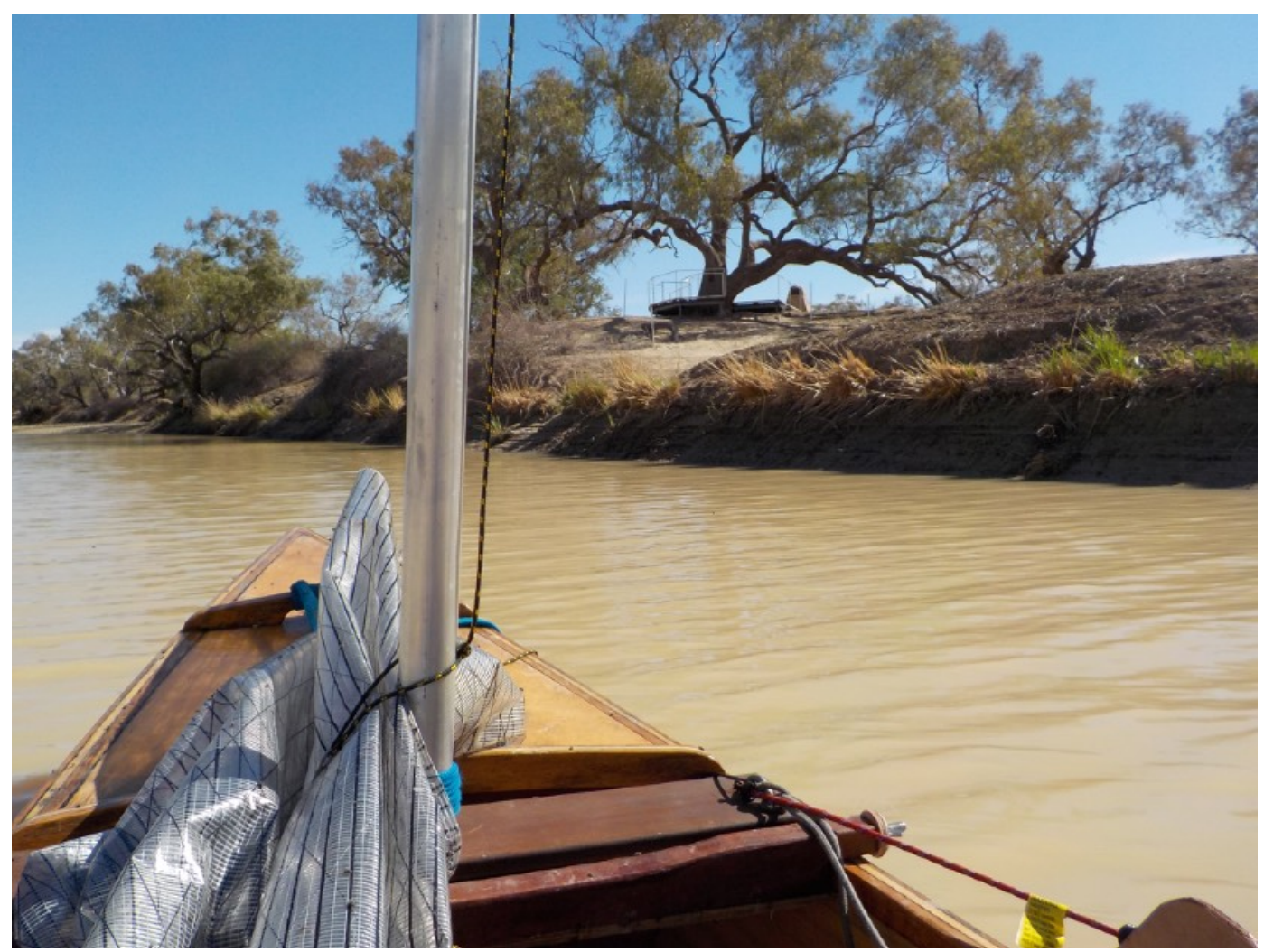

Figure 2. At anchor off the Dig Tree, Depot Creek

\section{The Project}

The project began, although not initially conceived as such, when I equipped a boat and four-wheel drive vehicle for expedition to Central Australia from the Queensland Gold Coast at the beginning of May 2018. The last sailing occurred on the fringes of the Simpson Desert in the first week of June 2018. The artistry and thinking of the emergent project were informed by both place and space, or "splace" (Reader, 2010, 2015). There was no clear plan as to where I, the artist, would travel or what bodies of water, if any, would be found. How such "discovered" places and navigations would "speak" into the project was also undetermined, but these would become part of the inquiry over time, each place speaking to the next, or referring to earlier concepts and images established along the way.

Journeying with boats in the dry interior of Australia is part of a European tradition, beginning with a widely held concept in $19^{\text {th }}$ Century exploration of Australia that the continent would contain an "inland sea," in much the same way that the North American continent has The Great Lakes, or Eurasia the Caspian Sea. Believing in an inland sea led John Oxley to persist in exploring New South Wales west of the Great Dividing Range in 1817-1818, carrying boats, but rarely using them. Captain Charles Sturt similarly carried a 
boat westward and successfully deployed the boat across the Murray Darling Basin to venture all the way to the Murray River mouth. On his Central Australian Expedition of 1844-45 he remained optimistic: "I have a strange idea...that there may be a central sea not far from the Darling in latitude $29^{\circ}$ and I should go prepared for a voyage" (Sturt, cited by Moorehead, 1965 p. 14). In the case of the Burke and Wills, a boat was included in the list of burdens believed to have contributed to the expedition's demise (Howitt, 1890).

Today the upturned "tinnie," an aluminium boat, is a common sight on the roof-rack of touring outback vehicles. Eccentric events, like "Henley on Todd" river race, where vessels and mock-ups of watercraft are carried along the dry sandy River Todd at Alice Springs is another feature of Central Australian boating culture. In South Australia, The Lake Eyre Yacht Club (LEYC), created by Bob Backway at Marree, is both a novelty tourism venture and a serious organizer of water events on ephemeral waters in the Lake Eyre Basin, if not on the Lake itself.

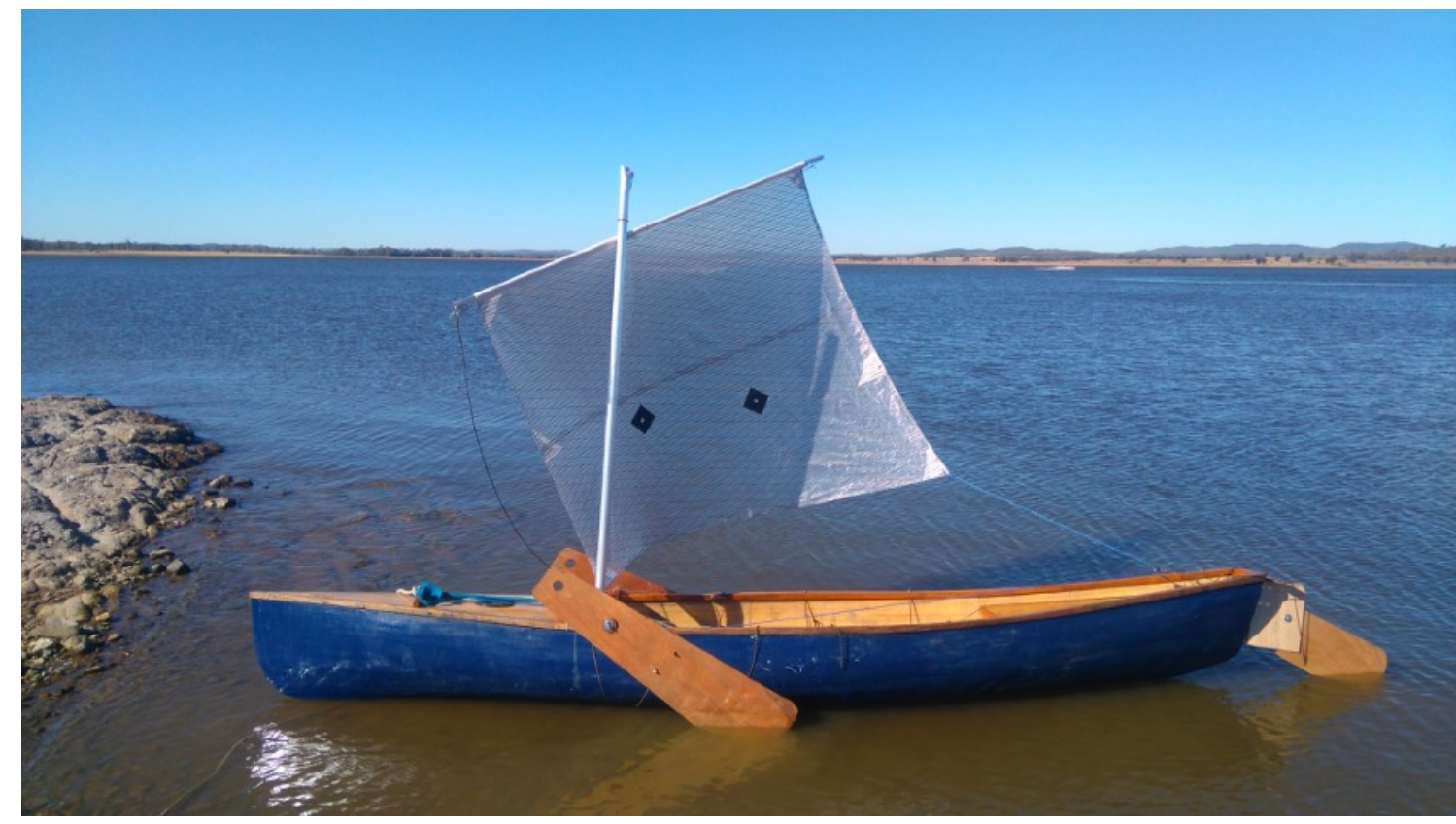

Figure 3. Mk 2 New England Swamp Boat, at Coolundra sea-trial with new lug-sail

LEYC's intention to sail the Warburton Creek on flows from Northern Queensland in early 2018 indirectly resulted in this project. I had planned to join the event, normally completed using motor-sailing catamarans. My intention, however, was to sail/paddle a canoe downstream and then walk out $160 \mathrm{~km}$ to the west rather than motoring back. The event was abandoned, due to insufficient flow/depth of water for the catamarans. By that stage, however, I was well into the preparation for a sailing encounter with the Warburton, if 
not to complete my original plan. The plan was not advanced enough to complete the walk out or retrieval, but I proceeded west regardless. From the Gold Coast, where I live, to the Warburton Creek on the edge of the Simpson Desert is about $2000 \mathrm{~km}$ across Queensland and the north of South Australia by road and track. This journey crosses the Murray Darling basin, the Cooper's Creek, Strzelecki and parts of Sturt's Stoney Desert to reach the objective. As should have been clear at the time, the journey west was to become another expedition and performance in itself. Before I embarked on any real expeditioning, however, I planned to conduct a series of "sea-trials" and modifications. The craft on which I based my sailing was nothing more than a pre-existing artwork, one imagined into existence as an earlier sculptural project.

\section{The Water-craft}

Rekindling my relationship with a Central Australian Aboriginal community in 2014 led to several visits to South Australia (Reader, 2016) and on a 2017 visit I took along my "canoe," an ambivalent exercise, in which the absurdity of taking any boat on roof-rack into the driest state on the continent had not escaped my attention. I justified this absurdity by intending to paddle it on the Spencer Gulf and where other opportunities occurred en route.

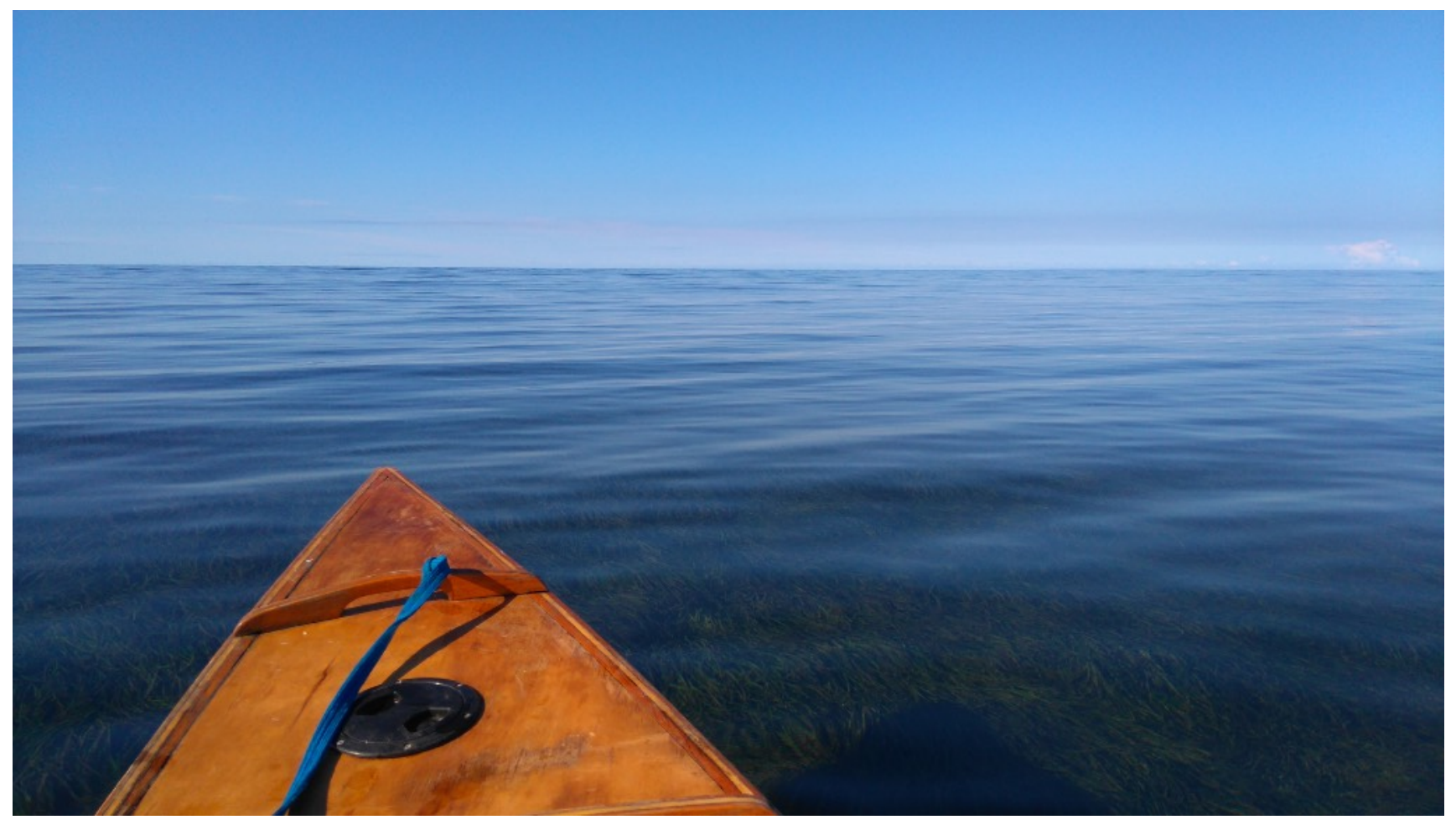

Figure 4. Only $60 \mathrm{~km}$ to Kangaroo Island 
Even more absurd was the nature of this canoe, a "featherweight" paulownia/glassepoxy construction (McCarthy, 1996) built from left-over materials and constructed purely from imagination. I imagined a "New England swamp-boat," coming from an imaginary history where Australia had been colonized much earlier than 1788. In a region where the only significant bodies of water are shallow swampy lagoons, a wooden swamp boat or gondola, might have replaced an Indigenous bark canoe well before the industrial revolution. With sleek bow and midships tapering to a raised transom, the stern was supposed to support a sculling oar, or more practically, in the current age, a solar-powered electric motor. In fact, the small beam and tapered stern did not support a standing paddler or sculler in the way a contemporary paddle board might. Sitting, however, the canoe is effortless to paddle using a single paddle "J" stroke method. It cuts through rushes and reeds without too much trouble, and can "climb," or slide over, shallow mud-banks, or beach very easily on soft shores, by punting. The handling proved consistent with how I imagined. Sailing however was to prove an entirely different experience.

The New England swamp boat proved unsuitable for places too deep or too off-shore, because recovery from capsize was impossible unless standing on the sea or river bed. Due to the lack of free-board, a swimmer cannot re-enter the craft, without re-submerging it. During this earlier trip, standing on the dunes of the Yorke Peninsula, on an unusually still day, I could just make out the line of Kangaroo Island $60 \mathrm{~km}$ away. "Yes!" I thought, "I could paddle there!" What a deception! I knew the Investigator Strait is rarely calm for long, and my survival of any such passage would have been an extremely lucky event. I paddled out over crystal clear water and sea-grass just far enough to take a photo. The image resonated in my mind and continues to hold a strange fascination. It set the stage for more adventuring and deceptive image-making.

It was also on this earlier journey that I first encountered the Lake Eyre Yacht Club and contemplated a refit for sailing rather than paddling. A series of prototypes and modifications, with outriggers, rudders and lee-boards, followed before and during this project expedition. This development is presented in the images below: 


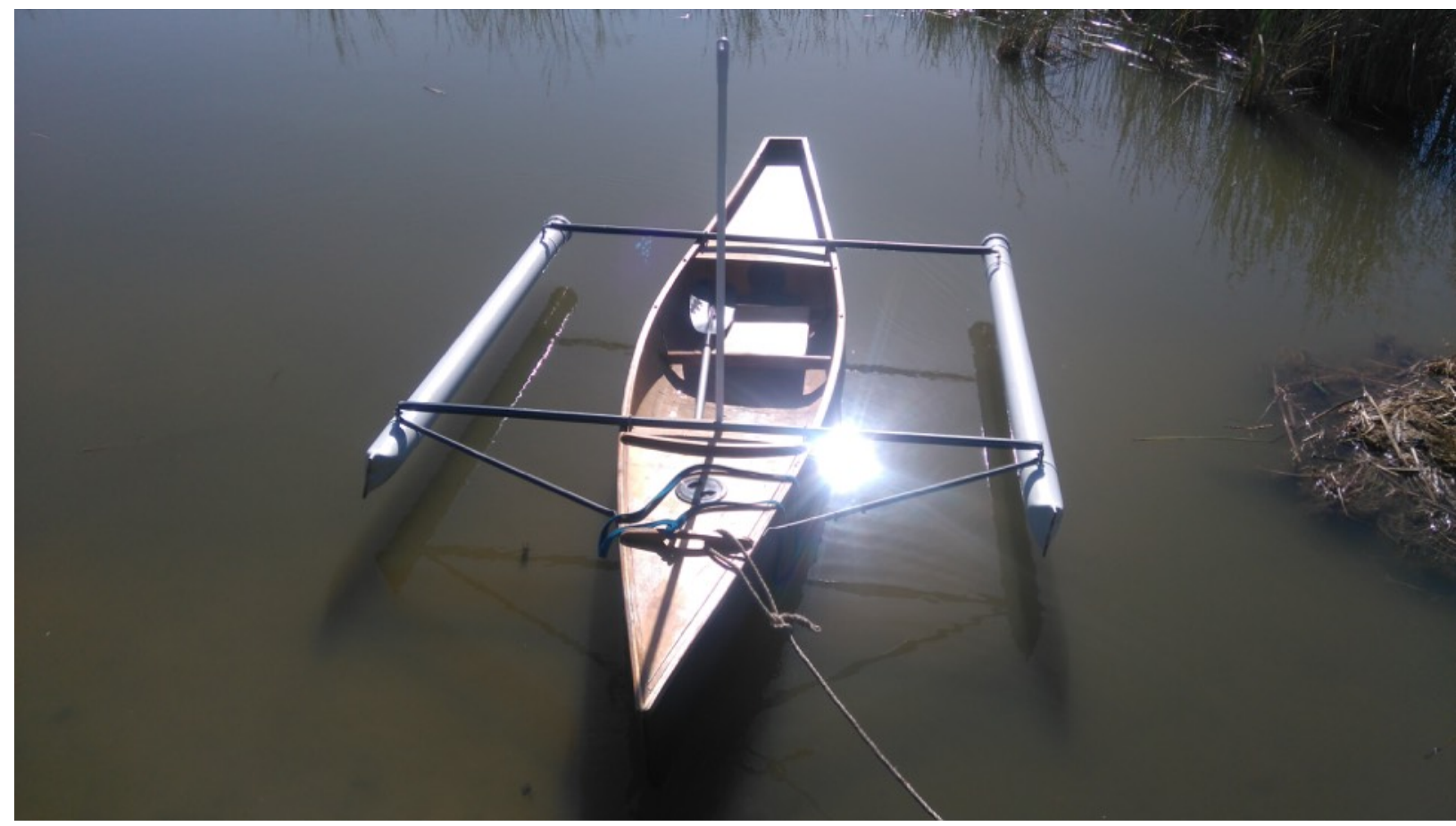

Figure 5. Mk1 with outriggers, was too heavy and drifted down wind. Shown here on first sea-trial Clayton Bay, South Australia.

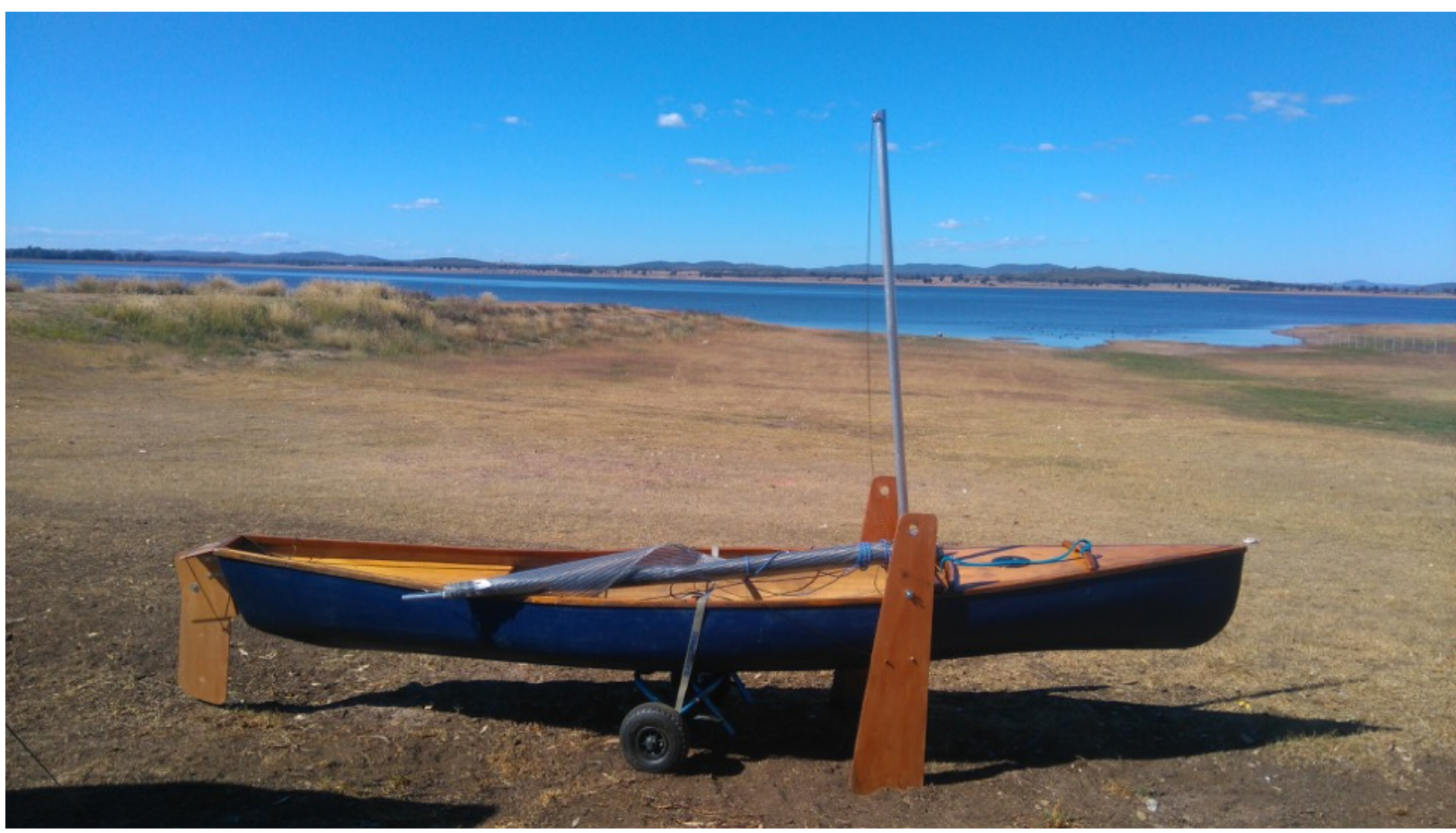

Figure 6. Mk2 with forward-mounted lee-boards. Difficult to tack and steer. 


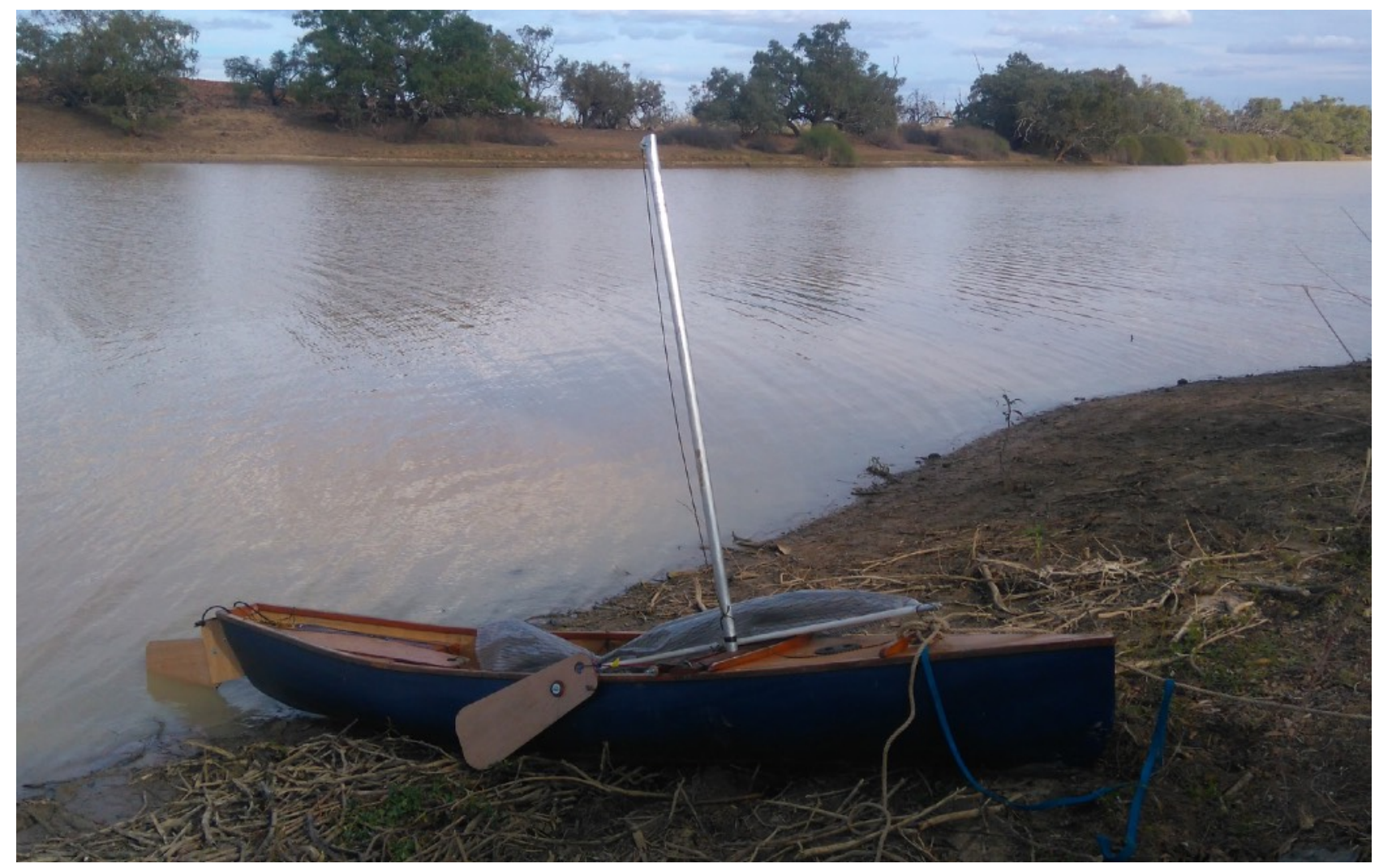

Figure 7. Mk3 improved at Noccundra with smaller lee-boards mounted amidships. Beached here, upstream of the Dig Tree, Depot Creek (Nappa Merrie).

\section{The Expedition}

Leaving the Queensland Gold Coast on $18^{\text {th }}$ May 2018, the first camp and trial of the new sail was at Coolundra, a water storage on the western edge of the Darling Downs. A range of light to fresh conditions were excellent for learning to sail the Mk2 craft. Tacking and steerage remained a problem, too much upwind advantage was lost in the turn across the wind, and the large leeboards were difficult to position often acting as a brake or steering device of their own accord. There were just too many variables for a single-handed operation.

Over the evening campfires, I contemplated making further modifications from the spare materials and tools I carried with me. The local culture of Coolundra also began to make an impression. Conversations of the campers carried from site to site in the silence of the still night air. During the day the itinerant campers, mostly with camper-trailers and offroad caravans would exchange histories and routes, and intentions. I began to imagine I had entered Greynomadia, a nation populated by retired and semi-homeless ageing Australians, commonly referred to as "Grey Nomads." They seemed to represent a special nation, 
holding strong opinions on a range of topics, from what they saw as the poor government of Australia to road-maintenance. Among the single men, the Family Court, which several held partially responsible for their current situations also helped shape a different world. While some were from Brisbane just touring for a week or so, others were long-term travellers, with "no end in sight to travelling" (Miller, 1986); in other words, expeditioners of both country and being in themselves. None, however, appeared to be heading west on the route I was taking towards St George, Thargomindah and across Western Queensland to the South Australian border.

After provisioning in Goondiwindi, I stayed just one night in St. George on the banks of the Balonne river, without unloading the canoe. With a slightly late start, my chances of reaching Innamincka, South Australia (SA) in one day, as I had on a previous trip, were slim. I began to question my haste. Even more so, I began to question my motives for travel; why was I returning to "SA"? Shouldn't I still divert back southeast into New South Wales? What exactly was my future? At this point I resolved to embark on a passage and a project to sail the Warburton Creek, regardless of what the Lake Eyre Sailing Club might do. Progressing further west, I moved deeper into Greynomadia, entering country explained and understood almost entirely through settler fictions reproduced in tourist brochures and interpretative displays. While Indigenous place names were common, their etymology, historical accounts and stories lacked depth or credibility. I wanted to write myself into the space that was neither Indigenous nor settler. I learned I was en route to the country where Burke and Wills had met their fate, and like them, I carried a boat. Would a sailing accident or ill-fortune deliver me a similar fate? Would I also become stranded in the same country with failing resources? Or would contemporary technologies deliver me from such a fate, if a wooden canoe and 1996 Holden Rodeo four-wheel drive count as contemporary? Would I, in the end, need to return to a more ancient resourcefulness, the kind I had observed among Indigenous men on a heritage project many years earlier (Reader 1983)? I was entering deepest Greynomadia with a basket of diverse resources carried on four rubber/nylon tyres. I was beginning to imagine and narrate the experience on my own terms, reworking the stories, signs and the interpretative tourist literature on offer.

Leaving Thargomindah in the mid-afternoon, I drove on past the Cameron's Corner (State border) turn off. The sun was going down and the next road sign informed me Innamincka was still over $250 \mathrm{~km}$ away. I was stuck in drive mode, driving for the sake of it, without any real appreciation of where I was or what I was doing. On this realisation, I stopped, made a three-point turn in the middle of the empty single lane "highway" and proceeded back to the junction where l'd seen a campsite and heritage site sign for $20 \mathrm{~km}$ towards Cameron's Corner. I'd stop for the night and re-appreciate my situation, in the morning, so I thought. 
As soon as I reached the free campsite on a waterhole, with a sign saying free showers, I knew I was in Greynomadia heaven. I would stay several days. I was thinking like an expeditioner; Burke and Wills increasingly ventured back to previous havens when fresh water did not open up before them. Here, a line of caravans along the bank and even a circle of wagons at one spot informed me that this was a well-recognized spot. The next day, I learned that this was the township of Noccundra, the most westerly surveyed town in Queensland. Only one lot, the Noccundra Hotel, was left in current use. There was little sign of a more occupied past.

I completed the Mk3 modifications at Noccundra. The waterhole was wide enough for me to conduct downwind and upwind trial sailings with the prevailing wind providing good reaching conditions at times. At last the boat was really sailing. By using an elasticated port or starboard draw-strings, the rudder was made to return to the neutral position, a muchneeded improvement to the steering.

At the shower block, I exchanged pleasantries with another traveller who had just arrived from The Dig Tree, where camping was very similar to Noccundra. The Dig Tree was intended to be a depot, a bridgehead, for survival of the Burke and Wills expedition, but communication and resupply proved fatally flawed. Out of these circumstances, my excitement of actually sailing these inland waters, the connections to the historical expedition, and the Wilson River's connection to the Cooper's Creek and the "Depot Creek," as Burke had named it, together with the sailing images, selfies of my sailing performance, all confirmed the idea I was "sailing in search of Burke and Wills." In exceptionally wet conditions, "Howitt the Rescuer" would have been unable to travel by horseback to Depot Creek, but travelling by boat might just have been possible on the falling current of these huge and often shallow flows. Howitt had been critical of the expedition carrying a boat, but my thoughts began to highlight how extreme conditions might lead to other less predictable outcomes.

In my possession, I had the beginnings of a portfolio of images taken as I, Howitt's successor, went in search of the suffering, starving and lost explorers. This was only the beginning, I would go on to discover the inland sea, and eventually have to abandon the expedition as conditions became unfavourable and resources were exhausted. 


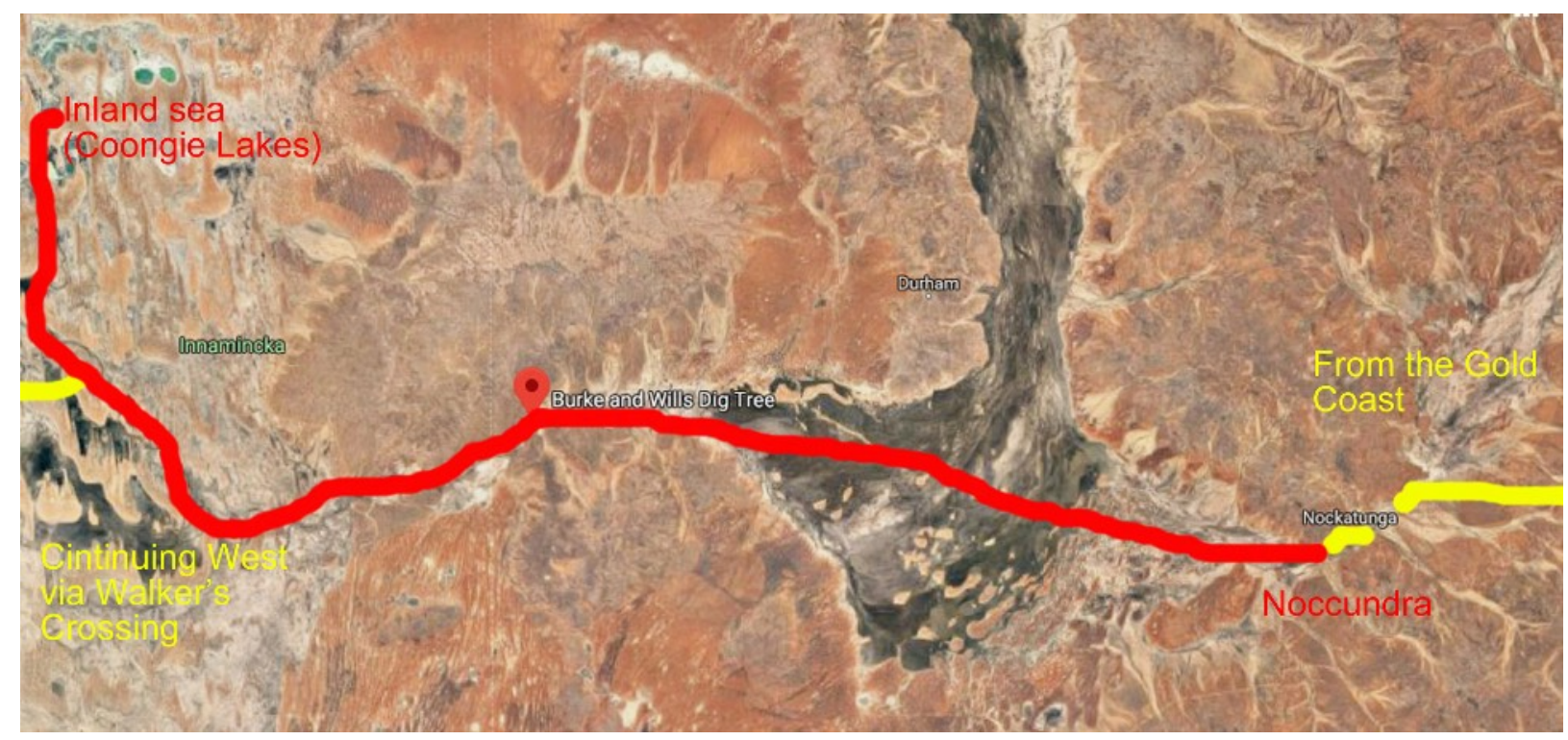

Figure 8. Theoretical sailing in a wet year

\section{The Discoveries}

Sailing down the Wilson River at Noccundra Waterhole, I had my first images and digital footage of the craft seriously sailing. A topographical map later revealed that under the right conditions the Wilson River could be sailed from Noccundra to Burke and Wills' Depot Creek (now called Nappa Merrie, reverting to its Indigenous name) and on further in search of an Inland Sea. In the 2012 flood, it would have been possible to launch from the pub carpark. Howitt's attempted rescue or a return via South Australia could not have proceeded against the current - horses could have been lost in a swim across the Cooper's Creek, or more than likely it would never have been attempted in adverse wet conditions.

Launching into the Nappa Merrie waterhole and sailing to the Dig Tree reach offered more images. I imagined myself with Mediterranean nautical procedures scaled down. I might have been sailing a 41 foot sloop for all it mattered. The water in the Dig Tree reach was shallow; I turned head to wind to anchor and drew the stern into the bank as if it were a finger wharf. I had moored at the historic site. It was here that Wills wrote:

Sunday $21^{\text {st }}$ April 1861 - Arrived at the depot this evening, just in time to find it deserted...Brahe communicates the pleasing information that they have started back today for the Darling, their camels and horses all well and in good condition; we and our camels being just done up, and scarcely able to reach the depot have very little chance of overtaking them....after four months of the severest travelling and privation, our legs almost paralysed, so that each of us found it a most trying task only to walk a 
few yards. Such a leg bound feeling I never before experienced and hope I never shall again. (Wills, 1861 cited in Moorehead, 1965 p. 98)

A cautionary lament for travellers in these parts who are ultimately failed by knowledge and technology.

Two weeks earlier, Coongie Lakes had filled with water flowing from the "channel country" and North Queensland. On arriving there, I paddled upwind to the lake from the camp site, sailed the open waters, and walked the Lake track to capture images of the Inland Sea. The inland sea became a photographic reality. I was treated to a view that explorers like Eyre, Burke and Wills, and Sturt were denied.
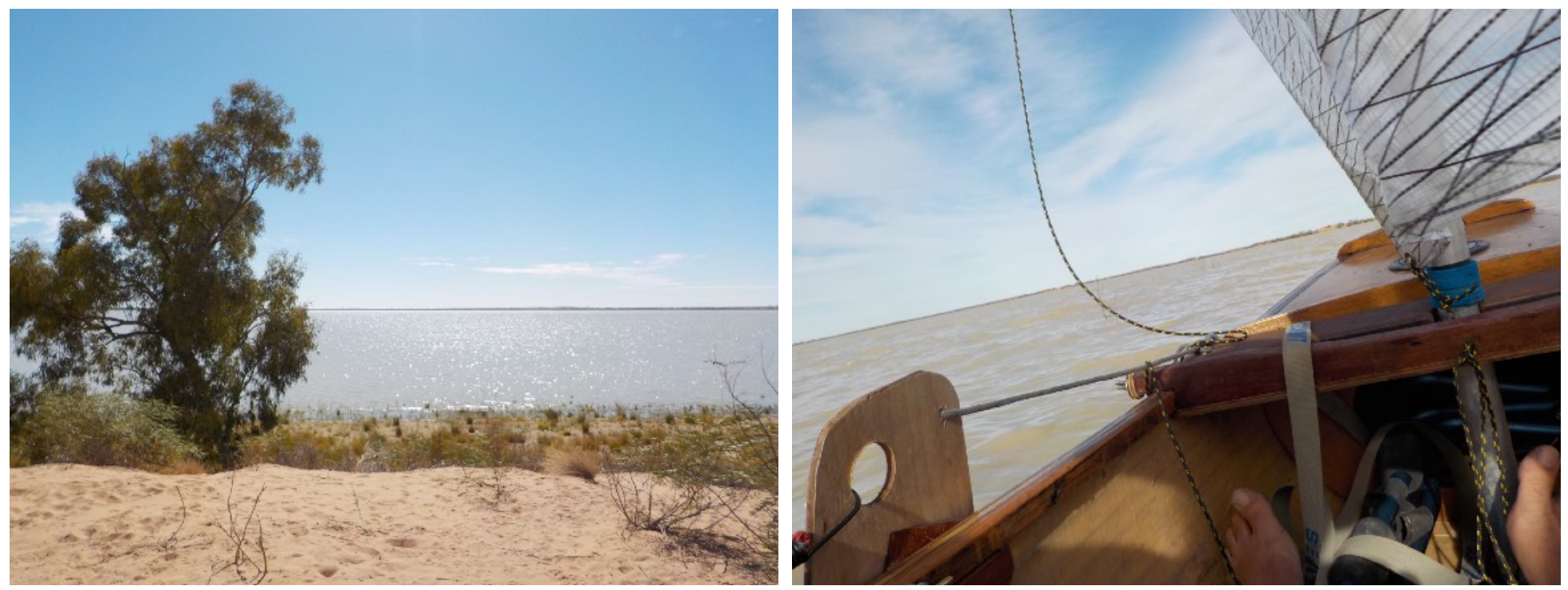

Figure $9(a \& b)$. The Inland Sea discovered

The drive on was via the Walker Crossing Track skirting the Strzekecki Desert/Sturt's Stoney Desert to the Birdsville Track the south to the Warburton Creek Crossing. Leaving Burke and Wills behind, passing their graves without even stopping, I went on in search of new fictions. The Walker's Crossing Track is an old way that crosses the dunes and interdunal flood plains. Every so often, the track would cross dead-straight petroleum company roads, clay highways with no public access, linking the gas wells back to their Moomba base. I felt like a Roman soldier caught in a time-warp. Modern motorways cross my journey on the Fosse Way, but I could have no part of them, they were not available for travel.

The junction of Walker's Crossing Track and the Birdsville Track is insignificant. Coming from the other direction one could easily miss the turn, were it not for an oil drum marking the turn. A roof-top boat at this point emphasizes the incongruity of the nautical 
experience in the desert. I was parked with a boat and this oil-drum signifier between the Simpson, Strzekecki and Tirari deserts. $80 \mathrm{~km}$ south, I turned off the Birdsville Track onto the Warburton Track to journey just $8 \mathrm{~km}$ to Warburton Crossing, but not before meeting new signs, the engraved wooden planks of official National Parks South Australia signage informing me I needed a Desert Parks pass, and that safety flags were mandatory.

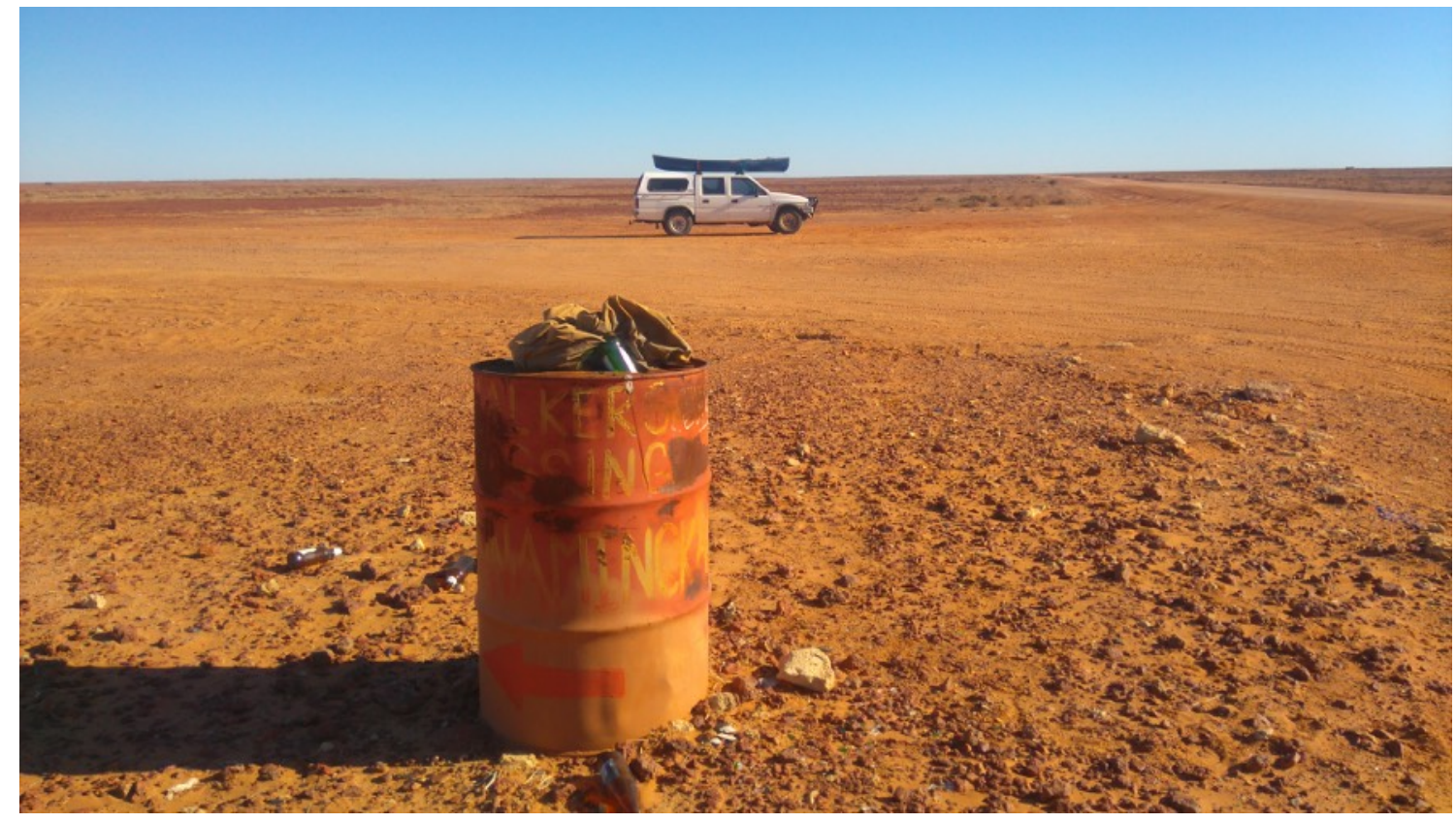

Figure 10. Between deserts with a boat

Once I raised my flag on repurposed boom of the Mk1, I had a new image and new imaginings. Beyond the Birdsville Track I had passed out of the Greynomadia world of towed homes. I was now in some new country, the image, mandatory flying of flags, reminded me of socialist republics, prayer flags, or perhaps zones declaring independent identity such as Åland. I imagined I had entered The Peoples Republic of Wangkagnurra.

The crossing was marked as a stock watering point, indicating a) that I was not yet in the Conservation Park, and b) that I could not camp within 500 metres. I set up camp $800 \mathrm{~m}$ back within $250 \mathrm{~m}$ of the track which theoretically complied with SA Pastoral Land Management and Conservation Act 1989. While I felt the heavy hand of government control, I also felt at home. I was on the fringe of Wongkangurru country, people I had worked with in the past. From the 1880s they had suffered intimidation and massacres, the survivors leaving the desert in four directions, forming and intermarrying with the Dieri, Lower Arrernte and other people. By the turn of the 20th Century, the surviving Wongkangurru had left the Simpson Desert "'never to return" (Hercus, 1985, p. 25). I felt one could declare an independent People's Republic of Wangkangurra every day of the week and no-one would 
do anything about it, other than perhaps the global oil companies wanting clarification of their tenure. It was the companies who originally introduced safety flags to avoid collision between vehicles approaching dune crests from opposite directions, but the idea of a white luminescent St. Andrews Cross in on a hi-viz orange background, seemed very apt for adoption of a Wongkangurru flag of independence. Most Simpson Desert adventurers flying it seem to come out fiercely independent and 2,000 miles from care. It really felt like any colonial government's ability to regulate and enforce policy in the desert was questionable at best. I began to play with aspects of flag flying, meeting policy standards, and four-wheel drive adventurism from the aspect of the sailor or canoeist. The 5 knots of current on the Warburton channel and headwind rendered sailing a liability, navigation was closer to whitewater canoeing.

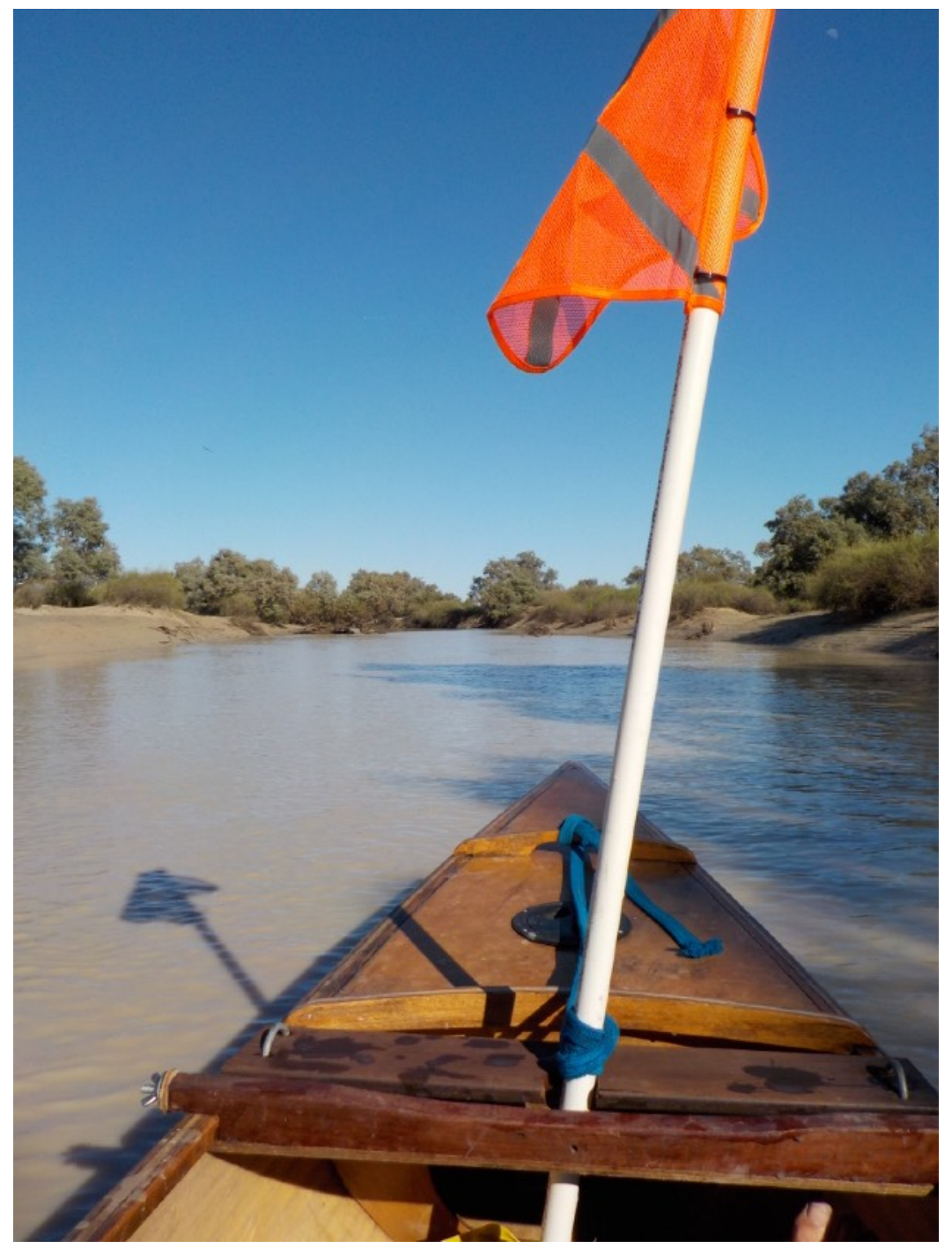

Figure 11. Navigating the Warburton 
Further South at Cowarie, I entered the Warburton again. The power of the flow was even more significant. I was ready to adopt my original plan to sail downstream to the top of Lake Eyre. Sorely tempting as it was, I wasn't organised with rations and footwear for the walk out. I had no strategy for an encounter with log-jams, snags or other impediments to progress. There was a chance I would meet the same fate as Burke and Wills. I was reminded of their graves at Innamincka and my own previous beckoning to cross the Investigator Strait.

It was the vacated space of the Wongkangurru that interested me now. I could at last understand how it was that Lewis (1875) discovered camps of more than 350 people. The flows on the Warburton bring down thousands of tonnes of organic matter and silt, whole trees are uprooted and later deposited somewhere across Kalamurina or as a berm at the lake's entrance to form new land. I was interested in mikaris, the way the dunes hold fresh water that will sit or be retained over more salty water by an inversion layer. I found green reeds growing out of seemingly dry sand, the type that only grow where there is fresh water.

\section{Reflecting on Inquiry and Future Applications}

The New England swamp boat, its carriage and sailing became an instrument of artistic inquiry. The resulting opportunistically acquired images stimulated new thinking around old stories and the imagining of alternative stories. The expedition to places in this vast space created new accounts potentially escaping "cultural authority" (Rubin 2012).

Will I use this initial inquiry to generate new artworks or new life directions? Probably not directly. More likely, I will investigate further and prepare for the eventual but unlikely possibility of sailing down the Warburton within my lifetime and walking out or being met from the other side of Lake Eyre. I dream that the end of the journey will continue to inform what may one day become a Wangkanguru heritage trail, a soft monument to the people who understood and lived north of Lake Eyre (and even as far south as Stuart's Creek).

It is important that artists continue to disrupt and question settler fictions. Images of sailing and water navigation of Australia's interior are just one small disruptive inquiry into this topic. Water, more so than artists, periodically disrupts this dry continent, yet, it is always seen as exceptional. As I looked out from the dunes at Cowarie across the Warburton flood plain in June 2018, there were only a few spots where the glint of sunlight catching water was visible. The view did not betray the millions of litres of water passing by every hour, or the water that has shaped this region and its people over millennia. 
I find myself challenging established understandings of Wongkangurra as mostly empty space, white paper, the Simpson Desert on the Australian map. Hercus working with Mick McClean focused on "people long[ing] for rain so that they could go out to the swamps, but the soaks were always there when all the surface water had dried out . . . [asserting] There can be no doubt about it, Wangkangurru people lived and died in the desert" (1985, p. 25). A maritime perspective as garnered by taking a boat into this desert re-situates the Wongkangurru as possibly a fishing and duck hunting people. Water does not necessarily come from rain, but can travel vast distances across Australia from the wet tropics. A boat provided a way to re-imagine a people and their economy.

So far, the mineral and petroleum exploration tracks and conservation park tracks avoid the area just north of Lake Eyre. The adjoining Kalamurina is still technically pastoral lease, however, it is managed for conservation values by a private conservator (Australian Wildlife Conservancy). I discovered in my imaginings and images the beginnings of a new contest between human occupancy as a threat and one of lost belonging.

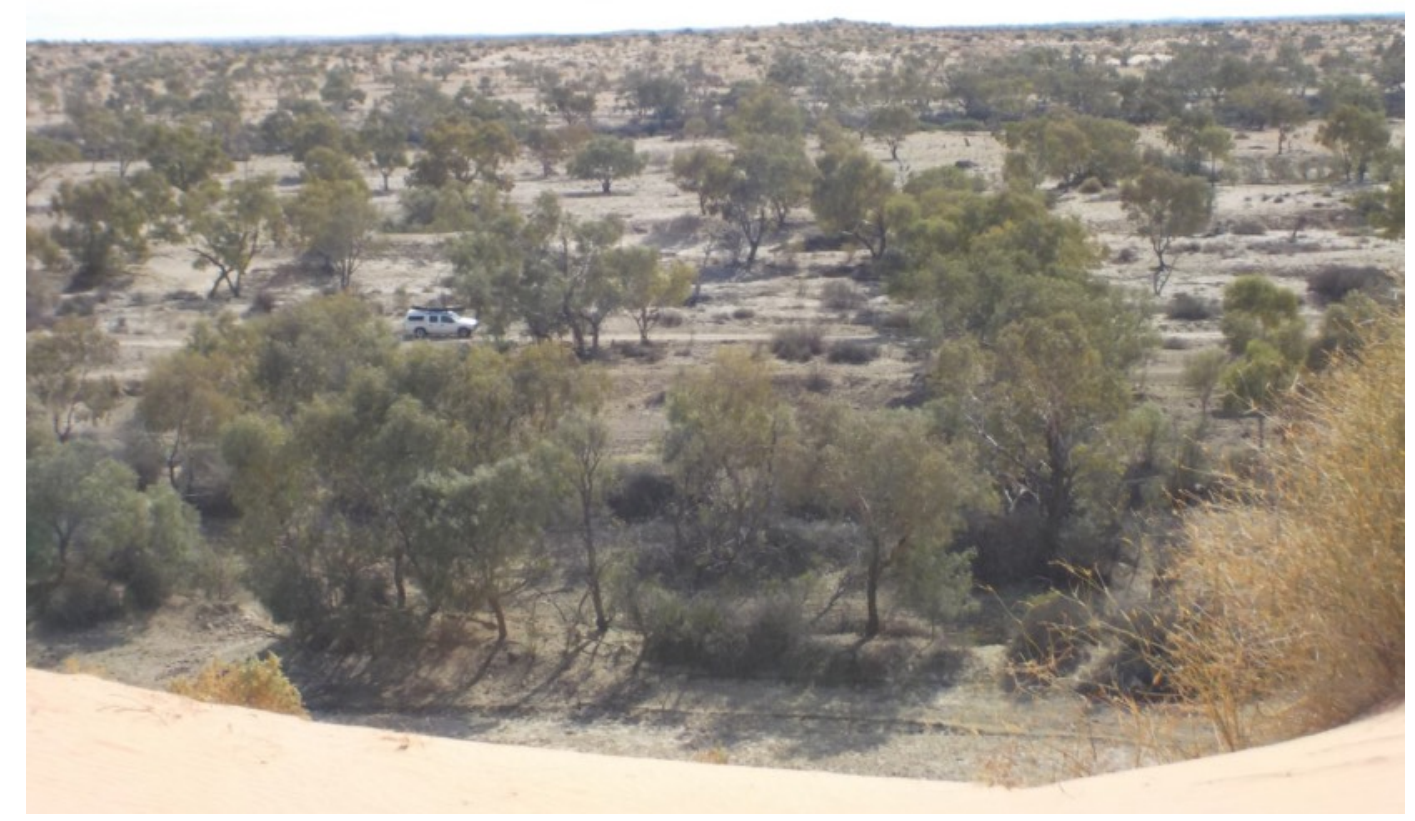

Figure 12. Millions of litres of water flowing past unseen 
In some ways, imagining a People's Republic of Wangkangurra captures the broader struggle for an Australian republic and Indigenous treaty that escapes the Indigenous/Settler binary. Burke and Wills were conceptually, but not technically, unsaveable. They died in the Cooper's Creek country where local people lived all around them and tried to save them. Even in a wet year, with the possibility of a lifeboat, it is unlikely they would have come out alive, yet still today, there is a part of Australia holding on to them tenaciously. Spaces that can afford many different stories and images are still dominated by their failure. SettlerAustralians carry boats into Central Australia perhaps anticipating the rarest of opportunities.

Greynomadia emphasises others' quests to affirm and discover settler history, while the imaginary vacuous People's Republic of Wangkangurra speaks to a vacated space which may yet come into being sometime in the future. I travelled between the polarities of the settler/Indigenous binary, between deserts and the images telling a story unbounded by traditional histories, a fantastical alternative. My appetite has been whetted for more work in Wangkangurru country. I wanted to understand the vacancy, the abandonment, the destruction, the loss. Paddling the Warburton, I was back to the arena of my previous heritage work in a new way. I had left the settler fictions behind, but wanted to know more about the few people who inhabit these spaces today and of others who might go on to give birth to a future flag of Wangkangurra or perhaps even birth to an Australian republic. This project allowed the application of visual imagery taken directly off of country - captured and viewed through the desert sailor's imagination, to encourage my life in yet further new directions and new performances.

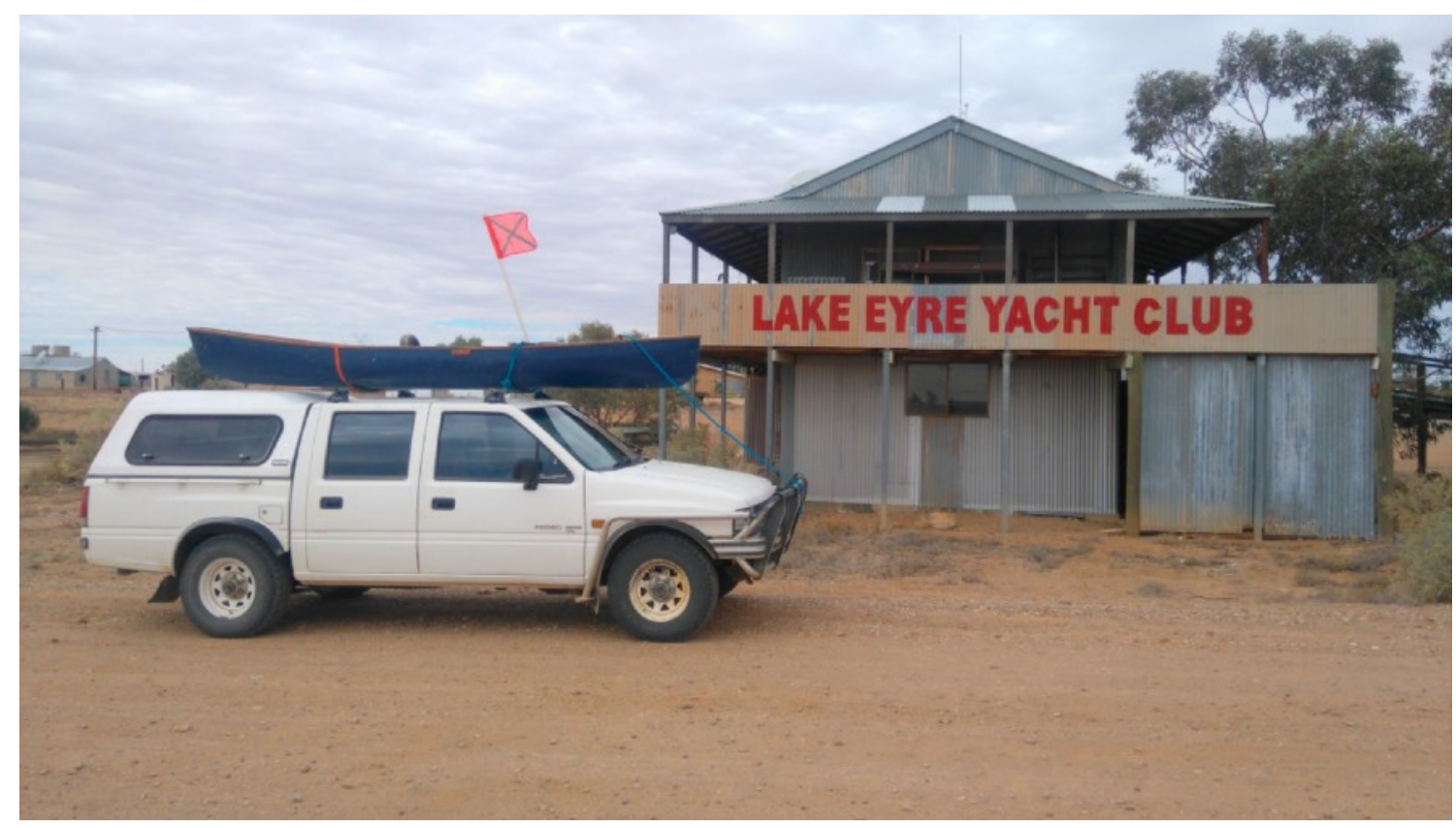

Figure 13. 


\section{REFERENCES}

Appy, C. (2000). Cold war constructions: The political culture of United States imperialism, 1945-1966. Amherst, MA: University of Massachusetts Press.

Charnley, J. (2015). Creative license: From Leeds College of Art to Leeds Polytechnic, 1963-1973. Cambridge, UK: Lutterworth Press.

Derrida, J. (1980). Structure, sign and play in the discourse of the human sciences. In Writing and difference (A. Bass, Trans.). Chicago, IL: University of Chicago Press. (Originally published in 1967)

Hercus, L. (1985). Leaving the Simpson Desert. Aboriginal History, 9, 22-43.

Hirst, D. (2007). For the love of god [sculpture: platinum, diamond and human material], White Cube Gallery, London, UK.

Howitt, A. (1890, April 15). The Burke and Wills Expedition: Reminiscences of the Rescuer [Lecture]. Queen's College, University of Melbourne. Melbourne. Retrieved from: http:// www.burkeandwills.net.au/Journals/Howitt/Howitt_1890.htm

Lewis, J. (1875) Journal of Mr. Lewis's Lake Eyre Expedition (1874-5). Adelaide, AU: Government Printer.

Lofgren, M. (2016). The deep state: The fall of the constitution and the rise of a shadow Government. New York: Viking Press.

McCarthy, H. (1996). Featherweight boatbuilding. Brooklin, ME: Wooden Boat Publications.

Miller, A. (1986). I see no end to travelling: Journals of Australian explorers, 1813-76. Manuka, ACT: Bay Books Pty Ltd.

Moorehead, A. (1965). Cooper's creek. London, UK: Hamish Hamilton.

Murgatroyd, S. (2012). The dig tree: The story of Burke and Wills. Melbourne, AU: The Text Publishing Company. 
Reader, P. (1983). The heritage of the Antikirinya, Arabana and South Aranda land. Unpublished report to National Estate Grants Program, Australian Heritage Commission.

Reader, P. (2010, Dec. 1). Ecological self-portraiture, reconnecting through transformative learning, tradition and transformation. Conference of the Art Association of Australia and New Zealand, Adelaide, AU.

Reader, P. (2013). Re-making fine art as inquiry into personal ecological/spiritual relationships. In L. Aguilar \& D. Curtis (Eds.) Linking art and the environment: Proceedings of the first ecoarts Australis conference (pp. 20-28). Wollongong, NSW: EcoArts Australis Inc.

Reader, P. (2015, April 16). Splace: Place in the space of walking. Far north, South Australia. Where to?: Steps Towards the Future of Walking Arts Symposium. Falmouth University, Falmouth, UK.

Reader, P. (2016). Knowing our place: Decentring the metropole through place identity in the Lake Eyre Basin. Postcolonial Directions in Education, 5(1), 55-81.

Rubin, A. (2012). Archives of authority empire, culture, and the Cold War. Princeton, NJ: Princeton University Press.

State Library Victoria. (2010) Dig: Burke and Wills. Terra Incognita: Education resource: Level 4 (Years 5 \& 6) Retrieved from: http://victoria.slv.vic.gov.au/burkeandwills/ index.html

Stonor Saunders, F. (1999). Who paid the piper? The CIA and the cultural cold war. London, UK: Granta Books.

White, L. (2009). Damien Hirst's diamond skull and the capitalist sublime. In L. White \& C. Pajaczkowska (Eds.), The Sublime Now (pp. 155-171). Newcastle upon Tyne, UK: Cambridge Scholars Press. 